\title{
A Journey Through Time
}

\author{
Jacqueline Passon and Said Hamid
}

\subsection{Caravan Trade in Ancient Times}

Jacqueline Passon

\subsubsection{Ancient Geography}

According to Herodotus, the description Libye/a was understood in ancient times to mean all of North Africa from Egypt to the "Pillars of Heracles" (Herodotus, Book IV), the straits between Spain and Morocco, which are now called the "Straits of Gibraltar".

The coastal landscape of present-day Libya is divided into three regions: Tripolitania in the west and Cyrenaica in the east, between which the approximately 700-km-wide strips of the Syrtis desert stretch out. In ancient times, these geographical conditions had already led to different developments: Tripolitania was more oriented to the west, and Cyrenaica more to the east. In the flat coastal plains of Tripolitania, the ruins of Sabratha and Leptis Magna constitute particularly impressive evidence of the Roman culture that was tied in with the traditions of Punic emporia (commercial settlements).

In contrast, the hilly coastal area of Cyrenaica has been populated by Aegean Greeks since the seventh century BC. Although this region was integrated into the Roman Empire, the connections of Cyrenaica to the Aegean region were still stronger than those to Tripolitania. ${ }^{2}$

J. Passon $(\bowtie) \cdot$ S. Hamid

Department of Physical Geography, University of Freiburg, Freiburg, Baden-Württemberg, Germany

e-mail: jacqueline.passon@geographie.uni-freiburg.de

\subsubsection{Phoenician Trading Posts in Present Day Western Libya}

At the beginning of the first millennium $\mathrm{BC}$, trade in the Mediterranean was in the sole hands of the Phoenicians. The endeavours of the Phoenician merchants led to the establishment of trading posts along the Mediterranean coasts in western Maghreb, on the Iberian as well as on the Italic peninsula, on Sicily and Sardinia. Over the course of the colonisation wave of the first millennium BC, the Phoenicians established trading posts in eighth century BC on the northern coast of Africa, which were initially only used seasonally.

The African coast between the Gulf of Gabès and the Gulf of Sidra is almost all flat, sandy and rather unwelcoming. The Phoenicians established trading posts, where their ships could anchor safely in the lee of a cape, where the trading routes from the African interior ended and where there was fertile land. Three of these outposts, which later carried the Roman names Leptis Magna, Sabratha and Oea, were developed into bustling urban centres. It was presumably the actual foundations of Carthage that dominated this coastal area for centuries. During this time, the Phoenicians came across nomadic inhabitants, who lived in tribes and belonged to one of the Hami Haitic ethnic groups. ${ }^{3}$

\subsubsection{Greek Colonisation in Present Day Eastern Libya}

The Greeks settled in eastern Libya and invaded the interior countryside in search of farmland. In $631 \mathrm{BC}$, the new settlers, who came from the island of Thera, won a larger settlement area around Cyrene. In this territory, which was later called Cyrenaica, they established several flourishing colonial cities, the capital of which was Cyrene. In response to this, the Phoenicians of North Africa gathered around Carthage and prevented further Greek settlement attempts. In 
the middle of the fourth century $\mathrm{BC}$, the borders to each of the spheres of influence were contractually determined. Hence, the Gulf of Sidra became the dividing line. As a result of the training of the successor states of Alexander's Empire, Cyrenaica was affiliated with Egypt and later with an outlying possession of the royal house of Ptolemies, the successor of Alexander in Egypt (323-30 BC). As the sole ruler of this region, Ptolemies Apion eventually bequeathed Cyrenaica to Rome in 96 BC. $^{4}$

\subsubsection{Roman Display of Power in North Africa}

The rise of Rome to a Mediterranean power triggered the so-called Punic Wars, which ended with the fall of Carthage in $146 \mathrm{BC}$. The Carthage region was a Roman province (Africa) right up to Fossa Regia. It marked approximately the border between the province of Africa and Numidia. The emporia, including Leptis Magna, Sabratha and Oea, ceded the Numidian allies to the Romans, who were content with just collecting taxes, so that the emporia actually enjoyed a factual independence. Within the escalating conflict between Rome and Numidia, three Tripolitanian cities formed an alliance with Rome.

During the Civil War between Caesar and Pompeius, the emporia made a pact with the Republican side. After the massacre of Thapsus (46 BC) and the associated defeat of the Pompeians, Numidia became the province Africa nova and former Africa became Africa vetus. As part of Africa nova, the emporia presumably fell under direct Roman rule at this time. Over the course of the Augustan provincial reform (starting in $27 \mathrm{BC}$ ), Africa vetus and Africa nova united to become the province Africa proconsularis, and the senate was presumed to be under the leadership of a proconsul. $^{5}$

\subsubsection{Pax Augusta and Economic Prosperity}

During first century AD, the ancient cities and settlements (civitates) began to achieve privileged Roman legal status (municipia, coloniae). Leptis Magna and her two sister cities, Sabratha and Oea, were subjected to a massive urban transformation in early imperial times, which strongly connected their vision of cities to a Roman city model. By building temples, public squares and houses, the inhabitants established organised municipalities, according to this Roman model. The changes brought about by this process affected not only the political organisation, but also the economic system, social structure and spiritual life. For rich and ambitious members of the upper class, it opened up the possibility of embarking on a political career in their hometowns. Through positions as the decurionate, aedileship, chief magistrate and provincial flaminate, one could attain even more influence, power, prestige and wealth. ${ }^{6}$

During the first three centuries, the emperor's rule ( $P a x$ Augusta) in North Africa was hardly challenged. It was only the region of Cyrenaica that suffered greatly from 114 to 118 $\mathrm{AD}$ under the attacks of an uprising by the Egyptian Jews.

\subsubsection{Caravan Trade as a Source of Prosperity}

It was within this context that Oea, Leptis Magna and Sabratha developed into prosperous cities. Their locations at the various trading routes between the Mediterranean coast and Africa's interior made them important settlements for trade and communication. The trans-Saharan trade became a significant source of wealth for the inhabitants. The cities functioned as stockyards and loading terminals. It was especially the trading of slaves, ivory, gemstones and wild animals, intended for games in the amphitheatre that played a central role.

The mediators of the trans-Saharan trade between Libya's Mediterranean coast and the African interior were an ancient people from the Fezzan region, the Garamantes. They inhabited the present-day Fezzan region since the fifth century BC, around the capitals of Zinchecra and Garama in the Wadi al Ajal (Wadi al Hayat). Horse breeding and the use of chariots enabled them to defeat the surrounding tribes. After initial military conflicts with the Garamantes, the Romans had given preference to diplomatic actions since the middle of the first century BC and facilitated the expansion of north-south trading. For their services, the Garamantes received Mediterranean luxury goods, amphorae filled with wine, oil or garum (fermented fish sauce) and glassware, as proven by the archaeological finds discovered in their settlements (Fig. 2.1). ${ }^{7}$

The caravans that crossed the Fezzan region brought the goods from Central Africa to the Mediterranean. There, ships took over the transport of the valuable products to the most important centres in the Mediterranean region. Intensive trading was practised with cities such as Rome. Many African cities had a trading station in Ostia, Rome's port. ${ }^{8}$ This is verified by pictorial representations and inscriptions on numerous mosaics at the Forum of Corporations in Ostia, which are partially still in good condition. The traders of Sabratha maintained a trading office in Ostia, as shown in the inscription STAT (io) SABRATENSIVM (Fig. 2.2). The picture on the mosaic of an elephant suggests that elephants or wild animals were traded too.

The Garamantes controlled the caravan routes from Africa's interior all the way to the Tripolitanian limes. Crossing the extremely arid landscapes was dependent on the few watering holes. The direct and shortest connection lead from Oea or Leptis Magna via Gharian to Mizdah and 

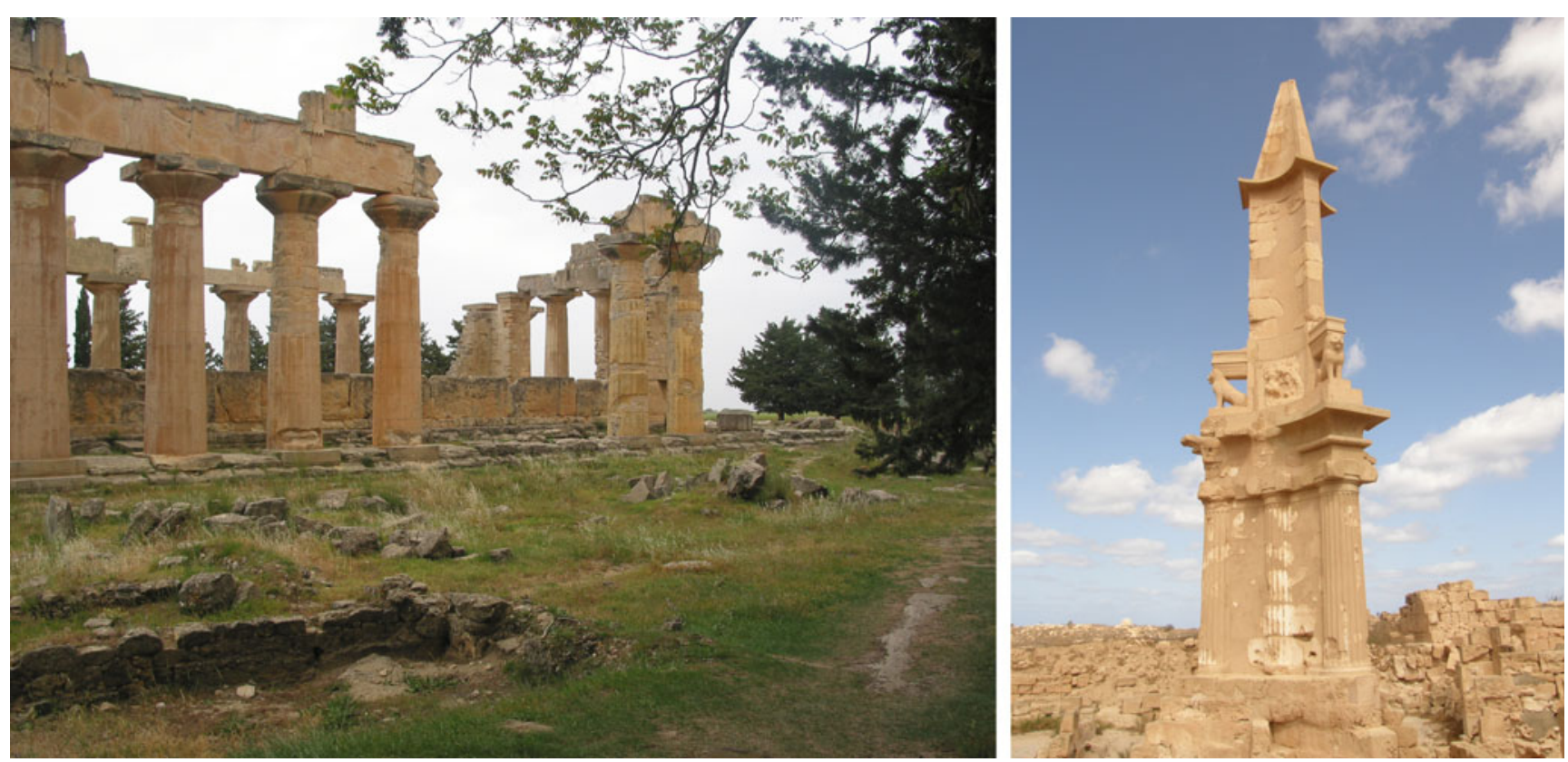

Fig. 2.1 Traces of the early settlements of Greeks and Phoenicians in Libya: The temple of Zeus in Cyrene is one of the best-preserved examples of ancient Greek art of architecture. In contrast, Punic traces like the grave in Sabratha are rare. Due to a directive issued by the Italian colonial authority, only remains of the Roman epoch could be excavated and restored
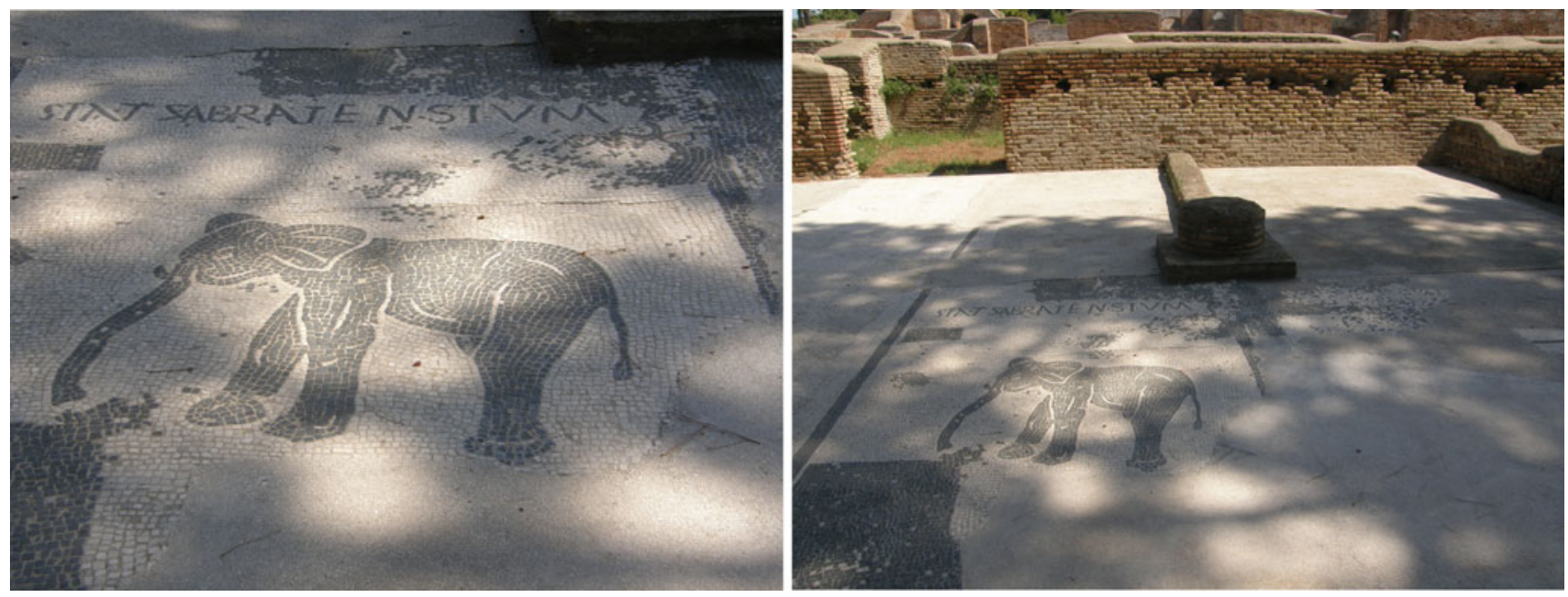

Fig. 2.2 Mosaics in front of the Sabrathian trader's office at the "Forum of Corporations" in Ostia. Ostia was the port of Rome, where many African cities maintained a trading station

to the military camp of al Qaryah al Gharbiya, and from there southwards through the Fezzan region towards Lake Chad and further into Africa's interior. Monitoring was carried out by the individual military outposts. There was also a western caravan route that ran from Sabratha via Ghadamis, or ancient Cydamus, through the Hoggar Mountains to Niger. An eastern road began at Leptis Magna and headed southwards past the fort Abu Nujaym. The paths between these fortresses could be relatively easily blocked (Figs. 2.3, 2.4, 2.5, 2.6 and 2.7). ${ }^{9}$

\subsubsection{Developments in the Late Antiquity}

Under the rule of the emperor Diocletian (284-305), an imperial administration was reorganised through the reclassification of the Roman territory into smaller provinces. The ancient emporia region in western Libya formed the independent province of Tripolitania. Cyrenaica was released by Crete and divided into two provinces: the western Libya Superior, which included all of the Pentapolis, and the eastern Libya Inferior. In the fourth century, the 


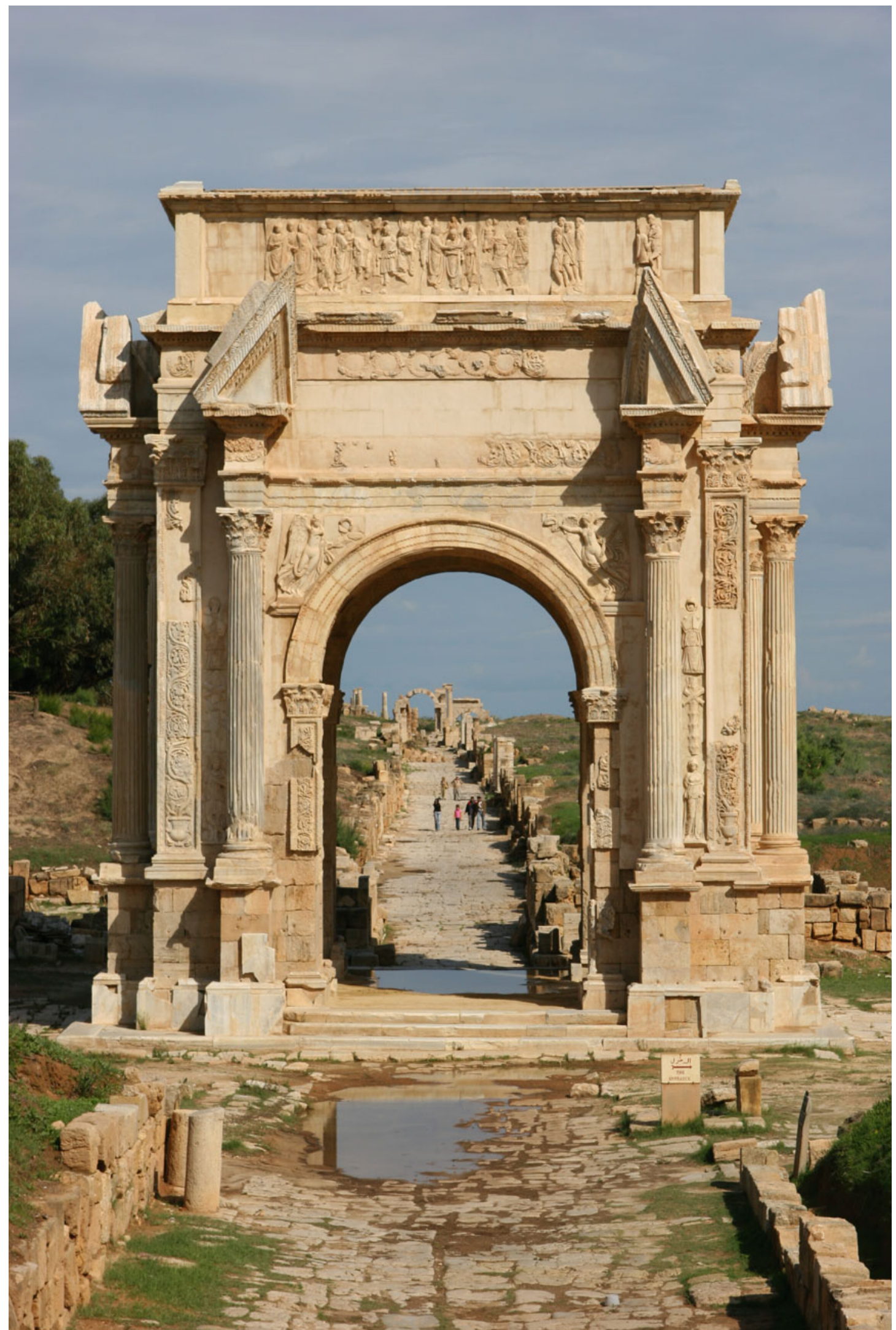

Fig. 2.3 Arch of Septimius Severus in Leptis Magna: Symbol of the prosperity of the ancient town during the second century 


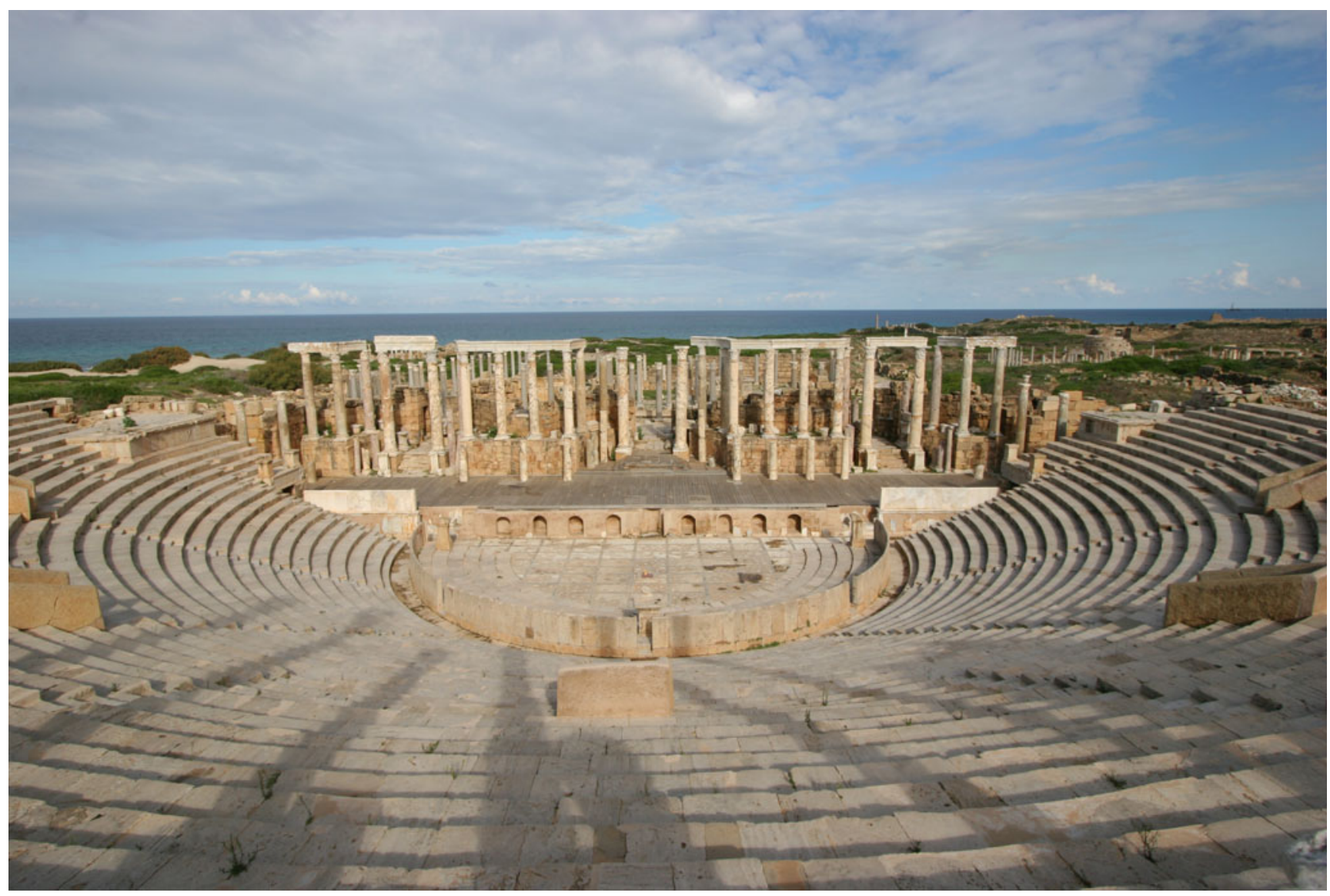

Fig. 2.4 Roman theatre in Leptis Magna: Entertainment nearby the sea
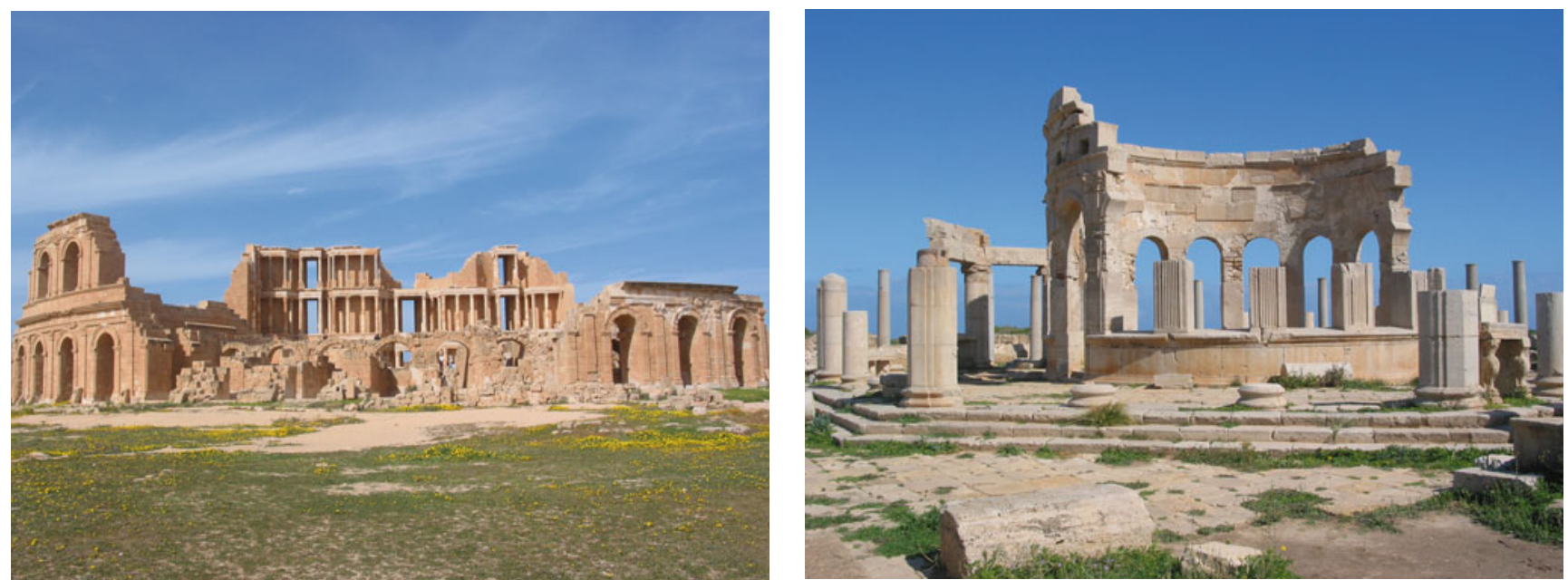

Fig. 2.5 Roman theatre in Sabratha

Fig. 2.6 Market place in Leptis Magna 


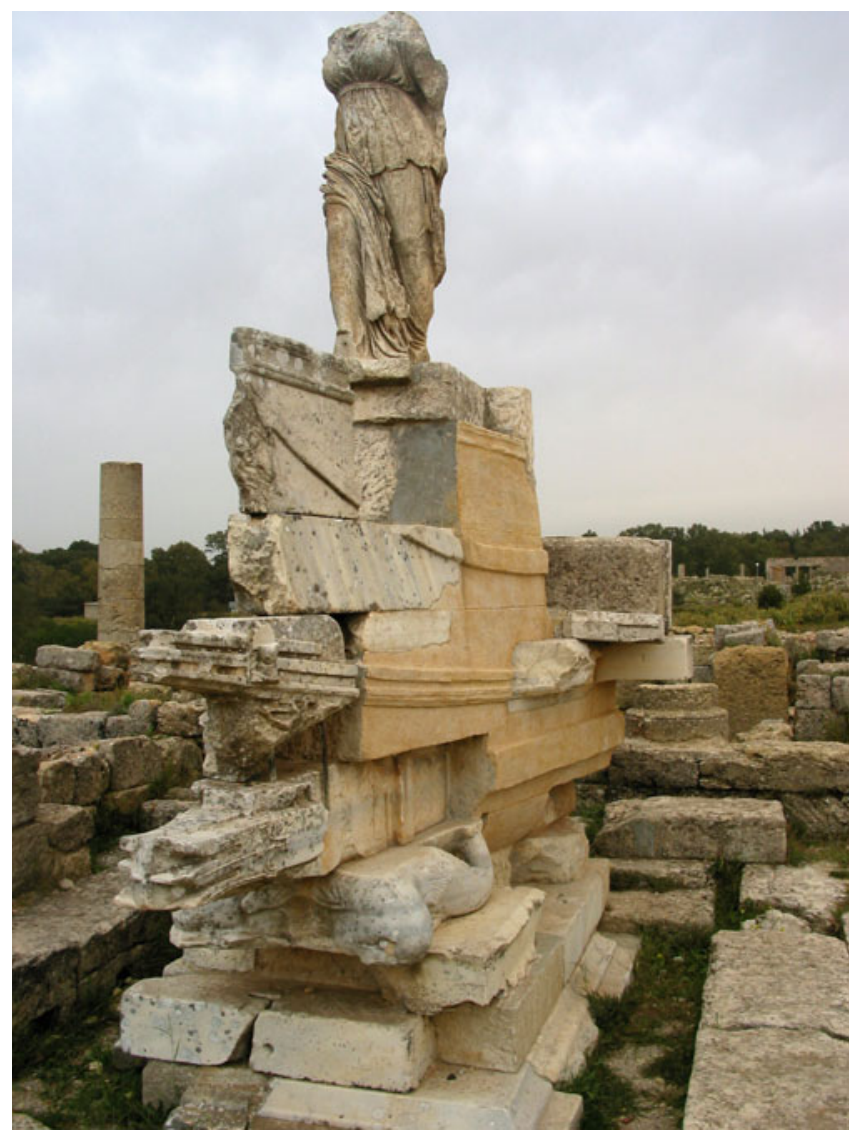

Fig. 2.7 Detailed view on Cyrene

Tripolitanians, like Cyrenaica, were subjected to increased pressure by the Libyan tribes. The effects of the mass migration also reached North Africa by the fifth century. Within a few years, the Vandals of the west had seized the North African coastal region. However, they did not cross the natural barrier of the Gulf of Sidra. They held their ground in Tripolitania for about one hundred years. Repeated attempts to win back the East Roman central power, Tripolitania and Cyrenaica, were finally successful in 534 AD under the leadership of Justinian. As with the Vandals, the Byzantine ruler only came into power along the coast of Libya. Byzantine fortresses in the cities elucidate the reduced size of the ancient centres. One Byzantine dux resided in each of Leptis Magna and Apollonia. The control of the country's interior was assumed solely by the strengthened Libyan tribes, who also increased their pressure on the coastal region. ${ }^{10}$

\subsection{The Light of Islam Penetrated the North of Africa}

\section{Said Hamid}

Islam appeared in Mecca as a result of the mission of the Arab Prophet Muhammad ibn Abd Allah, who preached monotheism and condemned the worship of statues. The Islamic religion spread across the Arabian Peninsula, and the Prophet was the nucleus upon which the Arab Islamic state was established. After the death of the Prophet, in the year $632 \mathrm{AD}$, he was succeeded by Abu Bakr as-Siddiq, the caliph who strengthened Islam in the Arabian Peninsula. He sent armies to take over Syria and Iraq; however, this was not achieved until the caliphate of Umar ibn al-Khattab. Control over Palestine and Egypt was taken later in the year 640 AD.

\subsubsection{The Arabs Take Over Libya}

When the Arab leader Amr ibn al-As took control of the city of Alexandria, it was incumbent upon the Muslim forces to control the Cyrenaica region which, historically and administratively, depended upon Egypt. This became imperative in order to secure Egypt's western borders from any possible Byzantine attacks and also to spread Islam. The Muslim forces were encouraged in their endeavours by the quick and stunning victories which they achieved against the Byzantines. Moreover, they were motivated by the situation of the people of Egypt, who did not consider the Muslims as invaders, but rather liberators who had put an end to Byzantine oppression. Supplies were guaranteed because of the Muslims' control over Egypt and the absence of any form of Byzantine resistance. Most Arabic sources mention different dates for the Arab victory in Cyrenaica. Despite Alexandria surrendered to the Muslims in the year $642 \mathrm{AD}$, Amr ibn al-As was able in the same year to triumph in the Cyrenaican cities of Tobruk, Derna, Susa and Tolmeita without any resistance. After the fall of the city of Marj, Tukra, Benghazi, Ajdabiya and Sirt shared the same fate, Amr ordered a campaign, under the leadership of Uqba ibn Nafi, which headed towards the interior regions. This campaign reached as far as the city of Zawilah. Another campaign, this time under the leadership of Busr ibn Abi Artat, was able to conquer the Waddan and other neighbouring areas, as al Hakam, a ninth-century historian, reports. It 
should be noted that there is doubt on the historicity, in particular, to al Hakam's account of the expedition to Fezzan.

Amr ibn al-As headed for Tripoli, and on his way, he took control of Leptis Magna. He then besieged Tripoli and was able to take it over in 643 AD. In Tripoli, Amr established his mosque, which is Africa's second mosque. He then sent his army, under the leadership of Abd Allah ibn az-Zubayr, to take control of Sabratha. Consequently, Amr led his army to the city of Sharus, one of the capitals of the Jabal al Nefusah region and brought it under his control. Before the overtaking of the remaining North African cities, Amr considered it prudent to consult the Caliph, Umar ibn al-Khattab. He wrote him a letter, saying: "God allowed us to be victorious in Tripoli. There are not more than nine days between this city and Africa. If the Commander of the Believers thinks Africa should be won, then this will be done". However, the Caliph did not agree to Amr's proposal. The latter was anxious about a possible return of the Byzantines to Alexandria and, therefore, hastened his return to Egypt. He left behind Busr ibn Abi Artat at the head of a garrison in the Sirt area and Uqba ibn Nafi heading a garrison in the Cyrenaica region. As far as the other regions are concerned, Amr kept no garrisons behind because he considered his conquests of such regions as an initial step towards a permanent Arab Islamic conquest to follow. It should be stated that no reference was made to any aggressive action on the part of the Libyan tribes against the Arab Islamic conquest. The Libyan tribes might have considered the Muslim Arabs as liberators from Byzantine hegemony which had long usurped their resources.

During the ensuing periods, there was a succession of Arab Islamic campaigns which sought to strengthen the conquest. The result of these campaigns was the conquest of Ghadamis in 662 AD. Moreover, Abd Allah ibn Sad ibn Abi Sarh dispatched campaigns against Ifriqya (Africa). According to the accounts of the inhabitants of the city of Awjila, he was the one who established a mosque in that city. When he died, he was buried in Awjila, where his tomb still can be found today. Ruwayfa ibn Thabit al-Ansari also raided Africa. He was the Amir (Prince) of the region when he died in Cyrenaica in the year $674 \mathrm{AD}$, and his tomb is still to be found in the city of al Bayda. By the year 674 AD, Libya was subject to the Arab Islamic state. It became a Muslim military centre from which Arab armies advanced towards the battles further inside Africa. It was towards this military centre that the Muslim armies retreated to reorganise themselves and, later, to resume their attacks.

After the martyrdom of the leader Uqba ibn Nafi in Tehuda in the year $683 \mathrm{AD}$, that same year Zuhayr ibn Qays al-Balwi, who fought within Uqba's army, retreated with the troops to Cyrenaica and was appointed governor of inner Africa. Upon receiving the necessary supplies, he raided inner Africa and made resounding victories. He then moved eastwards and, upon reaching Cyrenaica, found out that the Byzantines had recaptured it. He proceeded with 70 of his troops towards the coastal regions and engaged the Romans in an unequal battle. About the year $689 \mathrm{AD}$, he and all of his companions fought till martyrdom, and their graves, known as "the graves of the Companions", are still to be found in Derna.

Arab administration in Libya did not establish itself firmly before the time of Hassan ibn an-Numan, who had stayed for 5 years in the region of Sirt, waiting for supplies. There he built palaces, known as Hassan's palaces, remains of which can still be seen up to this day. During the 3 years of his stay in inner Africa (701-704 AD), Hassan dedicated his time to spreading Islam and the Arabic language and the establishment of Arab Islamic administration.

For eight centuries, Libya was subject to numerous Islamic petty states, such as those of the Fatimids and the Zirids. It was also part of the Almohad state and, subsequently, of the Hafsid state, before succumbing to the Spaniards in the beginning of the sixteenth century.

\subsubsection{Period of the Spanish Occupation (1510-1530)}

The end of the fifteenth century coincided with the rise of a Christian power, namely Spain. It managed to oppose the Arab Muslims and to bring about the fall of the last Muslim outpost in al-Andalus, Grenada, in 1492. Spain headed the fanatical Christian Crusades against Islam, and the Muslims, who had previously reached the zenith of their political expansion, were considerably weakened.

Soon thereafter, Spain's attention shifted southwards towards Morocco, and many cities, such as al-Marsa al-Kabir, Oran and Bejaya, succumbed to it. Subsequently, Spain set its eyes upon the conquest of Tripoli. With this aim in mind, the king of Spain prepared a military campaign entrusted to Pedro de Navarra who managed to invade Tripoli on the 25 July 1510 , following a strong resistance from the city's local inhabitants. When describing the battle in his report, the Spanish leader wrote the following: "There was no room to set foot, if not on corpses". Some sources state that the number of the Tripolitanian deaths reached five thousand, and another six thousand were enslaved.

The inhabitants of Tripoli soon organised themselves and adopted the nearby oasis of Tajoura as the centre for popular resistance. Since then, this city acquired a special place in the history of Tripoli. As a result of the local people's abandonment of Tripoli, as well as their strong resistance and lack of co-operation with the occupying authorities, the Spaniards tried to encourage the Christians, especially the Sicilians, to settle in Tripoli. To achieve this aim, the Spaniards offered the settlers many incentives, such as the 
provision of proper housing, the allocation of agricultural lands, exemption from all taxes for a period of 10 years, as well as civil and criminal impunity. Nevertheless, the call for settlement fells on deaf ears.

The Spaniards sought to fortify the fortress and the city of Tripoli, yet this task proved to be very difficult due to the resistance put up by the local inhabitants. In 1530, they preferred to cede Tripoli to the Order of the Knights of Saint John. In this manner, the Spaniards relieved themselves of a liability which was not to be overlooked and which had burdened the Spanish budget very much. Moreover, this move allowed the Spanish court to concentrate on its European problems.

The Spanish occupation was very damaging to the people of Tripoli. Many of them were killed, and huge numbers were enslaved and sold in the slave markets of Sicily. In addition, the commercial situation deteriorated very quickly, due to the lack of ships which sailed to the city's harbour. The popular resistance movement and the city's isolation from the coastal centres and from the interior resulted in a deterioration of the caravan trade. In addition, Tripoli lost many of its architectural landmarks, among them the Mustansiriya school and its grand mosque, along with many of its houses.

\subsubsection{Tripoli Under the Knights of Malta (1530-1551)}

The Order of Saint John hesitated to accept the Spanish offer of assuming the defence of Tripoli and its fortress. That was because, at that time, the order's weakness prevented it from assuming the responsibility of defending Tripoli and its fortress, especially since they were located amidst territories fuming with anti-Christian resistance. It was difficult for help to reach the order in this isolated area, especially since Ottoman naval units had started navigating in that region. The report prepared by the order's delegation, which visited Tripoli to scout the city's condition, was not encouraging. However, the order had no choice. The Spanish offer to cede Tripoli to the order was bound to the order's acquisition of the two Islands of Malta and Gozo, both of which could not be renounced. Thus, Tripoli was subjected to the Order of the Knights of Malta on the 24 March 1530. When they took over the city, they found themselves in a serious dilemma and in the midst of many dangers. For on the one hand, they faced popular resistance which was organised by the local inhabitants in Tajoura, and, on the other hand, they were exposed to the threat from the Ottoman fleet in the Mediterranean Sea. The means to defend Tripoli and its fortress were very limited, and during their occupation, the Order of the Knights of Malta did not leave any clear marks in Tripoli. This might be due to the fact that only fortified some sections of the fortress and of the city's bastions. In addition, the best halls of the saraya al-hamra (red castle), that is the main fortress in Tripoli, were turned into a church. In 1551, the Ottomans prepared a fleet which, with the help of the local inhabitants, managed to take over the city of Tripoli, and, consequently, Libya came under Ottoman rule. $^{11}$

\subsection{Libya in Modern History}

Said Hamid

\subsubsection{The First Ottoman Period (1551-1711)}

After extending their imperial influence across Europe, the Ottomans diverted their attention towards the North African territories, aiming to occupy them and add them to their empire. Libya was well within this sphere of interest, and, as a result, the Ottoman sultan dispatched a fleet, led by Sinan Pasha and Dragut Pasha. These sought to take advantage of the inhabitants' revolt, which was based in Tajoura, against the Knights of Saint John. Ultimately, the knights were expelled, and Tripoli was liberated.

Since 1551, Libya became part of the Ottoman Empire, and it was ruled by a succession of governors. Among the most prominent, was the first governor Murat Agha, who sought to fortify the city and its fortress, and who turned the church inside the fort into a mosque. He also built a mosque in Tajoura which still carries his name till this very day. Governor Dragut Pasha (1553-1565), in turn, also fortified Tripoli, and a mosque (Fig. 2.9) built a fortress which bears his name. He also established the gunpowder depot. The Governor Othman Saqizli (1649-1672) was responsible for the building of the markets, the public baths and a religious school. He also strengthened the naval fleet and entered into trade agreements with some European monarchies.

The last years of the first Ottoman period (1551-1711) were characterised by the control of the Janissaries over the ruling circles in the country. Their influence increased to the extent that they appointed and deposed governors according to their whims and interests. The country became corrupted, causing the local people, who were exhausted by heavy taxes to revolt against governors. This was a time characterised by great political instability and the struggle for power. 


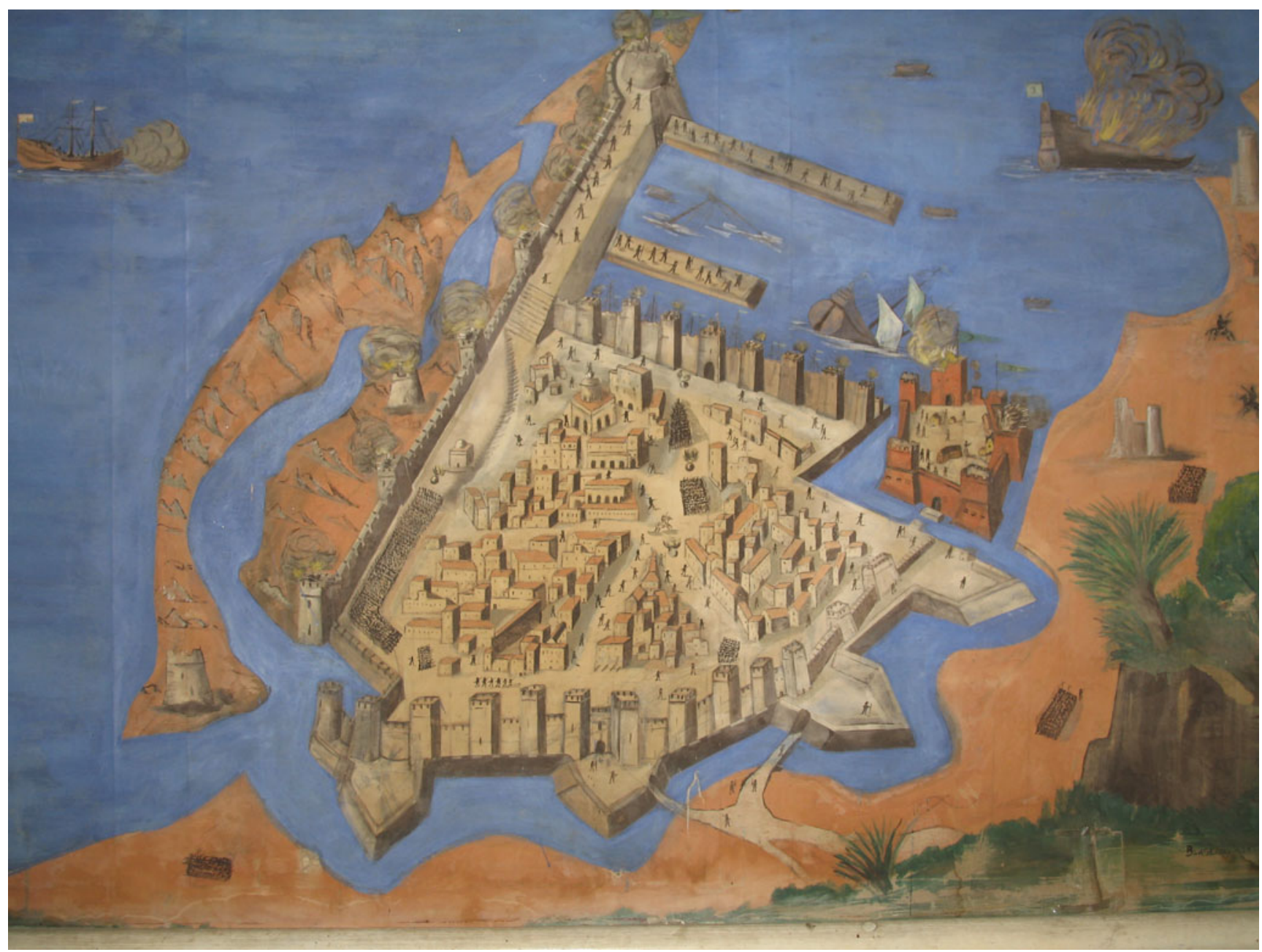

Fig. 2.8 Map of the fortified old town of Tripoli, the harbour and the red castle. The wrecks of the frigate USS Philadelphia and USS Intrepid, that went up in flames, can also be seen

\subsubsection{The Karamanli Period (1711-1835)}

The eighteenth century witnessed the beginning of the reign of Ahmad al-Karamanli, who had managed to realise his dream and become the ruler of Libya that he achieved by taking advantage of the weakness of the preceding rulers. He took control of the affairs of the country and established a hereditary type rule which lasted from 1711 till 1835 and is referred to as the Karamanli period. This historical phase was characterised by its independence from the Ottoman state and the establishment of diplomatic and commercial relations with some European countries, engaging in direct interaction with them without resorting to the Ottoman authorities. During this period, fortresses were built to oppose the periodical European attacks from the sea, and shipyards were established to build a Libyan fleet. Within a short period of time, this fleet became quite important in the Mediterranean. Moreover, Arabic became the language of the state's institutions. The Yusif al-Karamanli period
(1795-1832) witnessed the Libyan-American conflict in the Mediterranean Sea, during which the Libyan people resisted the American attacks and attempts aimed at securing the passage of American commercial ships. History has recorded the story of the capture of the American vessel Philadelphia by the Libyan navy in 1830 (Fig. 2.8). This was the second largest American naval unit and carried 307 officers and troops. America took advantage of the presence of Ahmad al-Karamanli, the brother of Yusif Pasha, in Egypt and encouraged him to return to Libyan rule, supplying him with weapons and facilitating his attack against Tripoli, starting from Derna. Events followed in quick succession until a treaty was signed between Libya and America. On the basis of this treaty, Libya handed over the American captives and, in return, received compensation. Furthermore, America turned its back on its agent Ahmad al-Karamanli.

Towards the end of the Karamanli rule, Libya faced an economic crisis which came as a result of its weak financial resources, particularly after the decline in maritime activity 


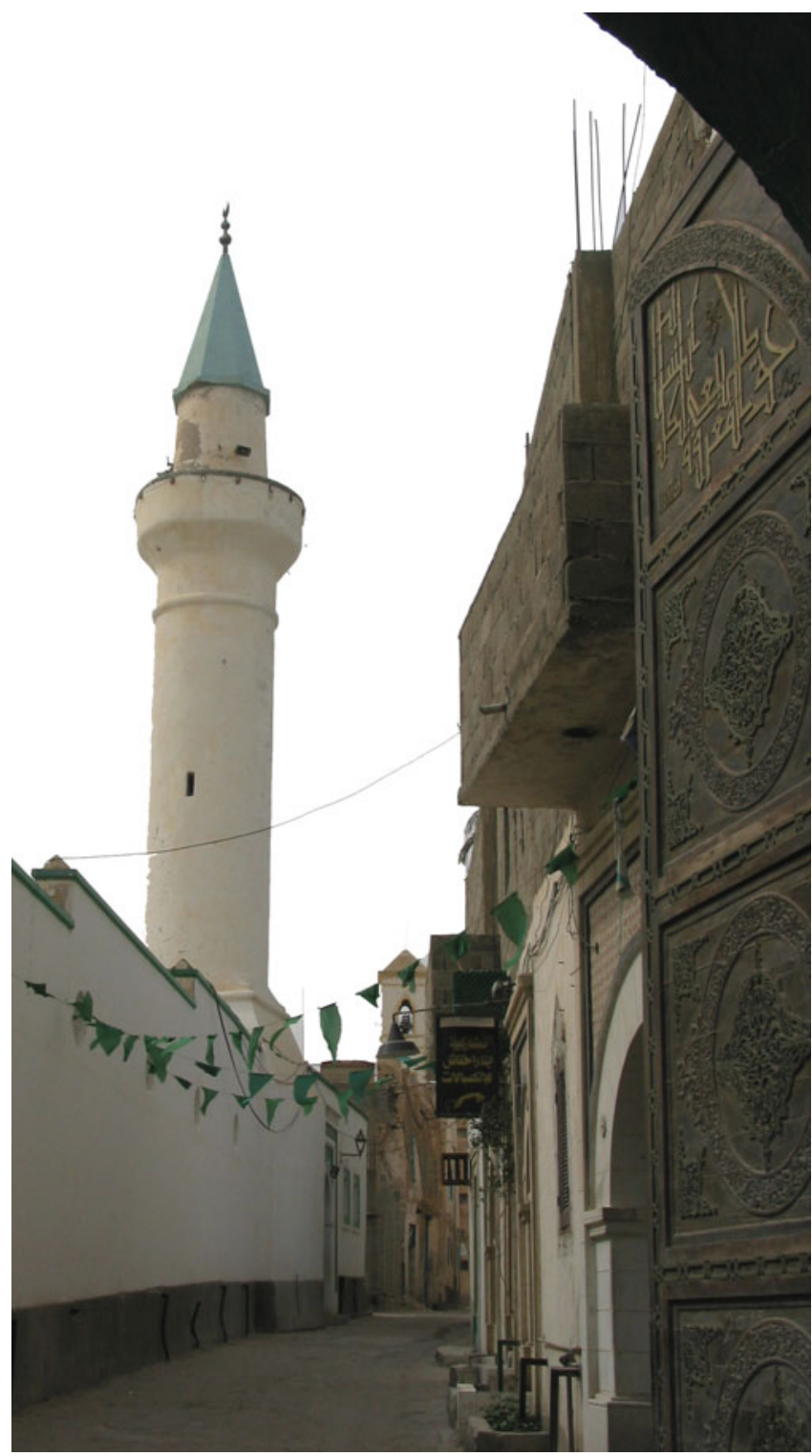

Fig. 2.9 Mosque of Dragut Pasha, who was a governor of Tripoli during the first Ottoman period between 1556 and 1563. This mosque is one of the largest mosques in the medina of Tripoli

and the abolition of slave trade. In an effort to curtail the budgetary deficit, Yusif Pasha borrowed money from foreign traders, burdened the population with taxes and changed the currency eleven times. On their part, the foreign consuls intervened in matters concerning the rule of the country and, as expected, a revolt broke out against Yusif Pasha in al-Manshia, calling for his deposition and for the appointment of his grandson Muhammad as ruler of the country. The Ottoman state sought to calm the situation in the governorate, whereas the French and English consuls seized the opportunity to interfere in the struggle for power. Conscious of his inability to handle the events, Yusif Pasha had no alternative but to renounce power in favour of his son, Ali
Pasha (1832-1835) who managed to secure the approval of the Ottoman sultan for his appointment as governor. Nevertheless, the revolt of the inhabitants of al-Manshia continued unabated.

\subsubsection{The Second Ottoman Period (1835-1911)}

The Ottoman state decided to settle the Libyan question and restore its sovereignty over the governorate of Tripoli. It was anxious about the European ambitions concerning the occupation of Tripoli, particularly after the French occupation of Algeria in 1830. For this reason, the Ottoman sultan sent a fleet to secure Tripoli, which became, once again, an Ottoman governorate.

At this time, the country witnessed a number of revolts against Ottoman rule. Foremost among the Libyan resistance leaders were Ghuma al-Mahmudi and Abd al-Jalil Sayf an-Nasr, but these revolts were suppressed. Some governors, in an attempt to improve the conditions of the governorate, were able to introduce a number of reforms. For example, civil and military schools, hospitals and post and telegraph offices were built, wells were dug, and a printing press was imported for the publication of newspapers and magazines. Furthermore, it was a time in which Libya witnessed a considerable architectural boom (Fig. 2.11).

For its part, Italy's ambitions to occupy Libya were evident. In order to pave the way for such an endeavour, Italy took a number of economic and political measures. Notwithstanding the attempts of some governors to resist these colonialist ambitions, Italy exploited the weakness and problems facing the Ottoman state and managed to occupy Libya on 7 October 1911.

\subsubsection{The Italian Occupation}

By the end of the nineteenth century, Italy's occupation ambitions became clear. The governorate of Tripoli was the last governorate under Ottoman control. The Ottoman state had become unable to protect the integrity of its territories. At the same time, Italy prepared for the occupation of Tripoli. At exactly 2.30 in the afternoon of 28 September 1911, the Italian minister of foreign affairs, di San Giuliano, submitted a memorandum to the Turkish grand vizier which stated: "The Italian government ... has decided to occupy Tripoli and Cyrenaica militarily". Following this communication, Italy entered into a state of war with Turkey and took the necessary military steps to execute the occupation. On 3 October 1911, the Italian navy started to bombard the Libyan coastal cities, and, on 5 October, Italian forces landed on Libyan soil. The Libyans called for jihad, a war of resistance, against the invaders. Epical battles were fought in 

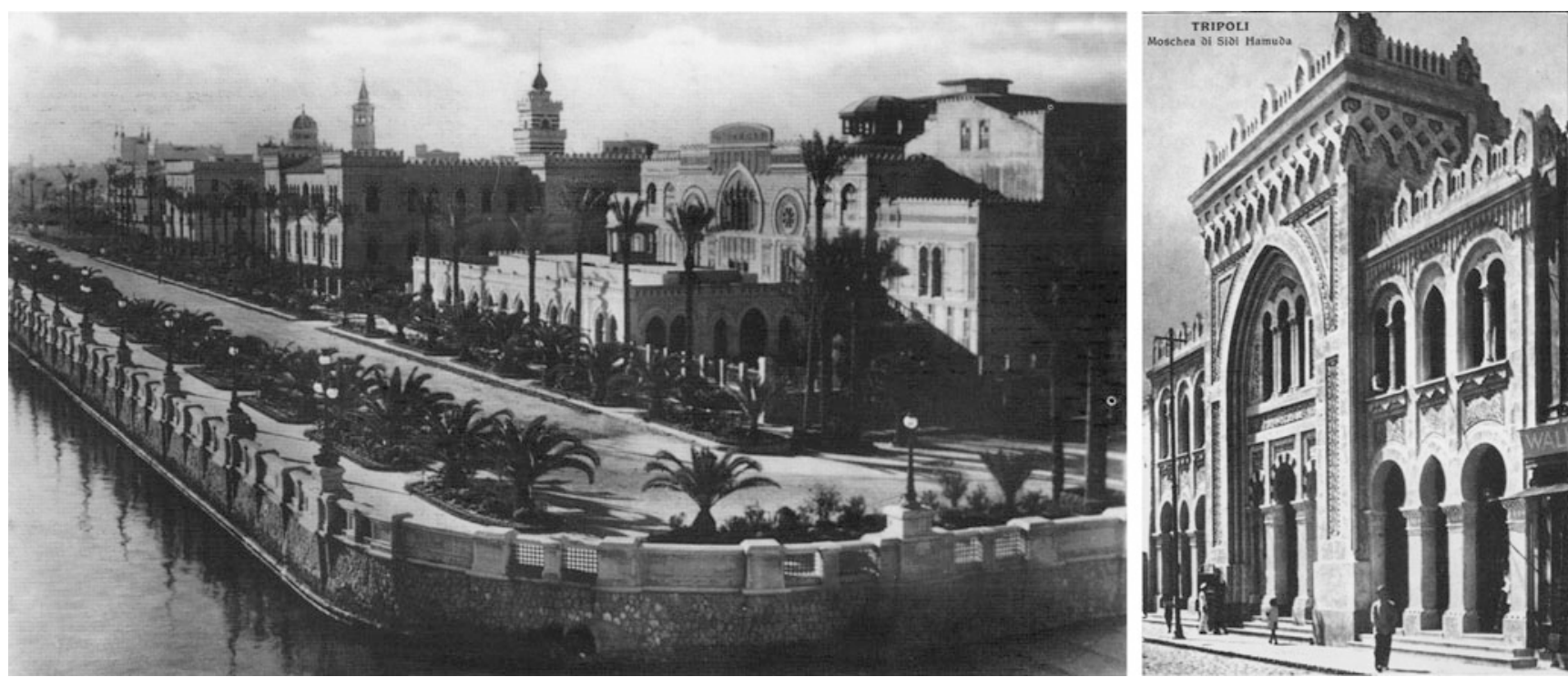

Fig. 2.10 Italians and their idea of a new urban design for Tripoli: At the seaside, they built the Lungomare Conte Volpi, a promenade lying towards the sea with the Miramare theatre in the foreground. On the right side: for the old Sidi Hamuda mosque, situated at the corso Vittorio Emanuele III, the Italians designed a Moorish facade (Laronde 1997)

Jiliana, al-Hani, Shari ash-Shatt, al-Murgub and elsewhere, in an attempt to defend religion and the Libyan soil. Faced with such fierce opposition, Italy tried to evacuate the land of its inhabitants. To achieve this aim, it started to carry out the most brutal deportation in history. Thousands of Libyans were deported to remote Italian islands. The first of such deportation campaigns was put into effect on 26 October 1911. In the face of the huge Libyan resistance, and having suffered a number of humiliating defeats, the Italian forces were restricted to an area which did not exceed the shooting range of its fleet. In the meantime, on 18 October 1911 in Lausanne, Italy signed a treaty with the Ottomans by which the Ottomans renounced Libya. The Libyans had, by now, lost all hope of Ottoman support and had to rely on their own resources in their fight against the Italians.

The Italian forces occupied several Libyan cities, such as Gharian, Sirt, Zawia and Ujailat, and managed to reach as far as Marj, in the east. The Libyan freedom fighters engaged the Italians in many intense battles, such as the battles of Jdabia, Sidi Krem al-Girba, in the Green Mountain. The Libyan fighters also resisted the Italian forces in the Fezzan. The battles of ash-Shabb, Ishkda and Mahruga were heated battles in which the Italian troops were forced to retreat, particularly after the battle of al-Gara, in Sebha. Italy tried to re-occupy the Fezzan, the region which controlled trade movement and the most important caravan roads linking the Libyan ports with the African interior. However, Italy suffered a great defeat in the Gordabiya battle on 28 April 1915.

In 1922, the Fascist party came to power in Italy. This party adopted a policy of extreme brutality towards the Libyans and resorted to executions without trials. It sets up concentration camps in Libya, most renowned of which were those of al-Agila, al-Magrun and Slug, in which thousands of Libyan prisoners were crammed, in an attempt to isolate the population from the freedom fighters. The most prominent of these fighters was Sheikh Omar al-Mukhtar, who was arrested and later executed on 16 September 1931.

Italy confiscated Libyan land and distributed it among the Italian colonists (Fig. 2.10). The Libyans were recruited to take part in Italy's colonialist wars in Ethiopia. They also formed part of the Italian army during the Second World War. Libyan lands were also converted into minefields which took their toll on man and greatly hampered the area's development. At the end of the Second World War, Italy was forced to withdraw from Libya. Italy left a destroyed and devastated Libya behind, which at the time became one of the poorest countries in the world.

\subsubsection{After the Second World War}

After the Second World War, Tripoli and Cyrenaica came under the British mandate, whereas the Fezzan came under French mandate. In the meantime, the Italian community retained its control over the country's economic resources. In the wake of the declaration of independence on the 24 of December 1951, Libya entered a new phase in its history as the United Kingdom of Libya. However, the country lacked state economic recourses and expertise. Poverty and illiteracy among the people were widespread. In fact, the Libyan state had to rely on foreign aid. The country witnessed a number of crises which left their mark on the country. 


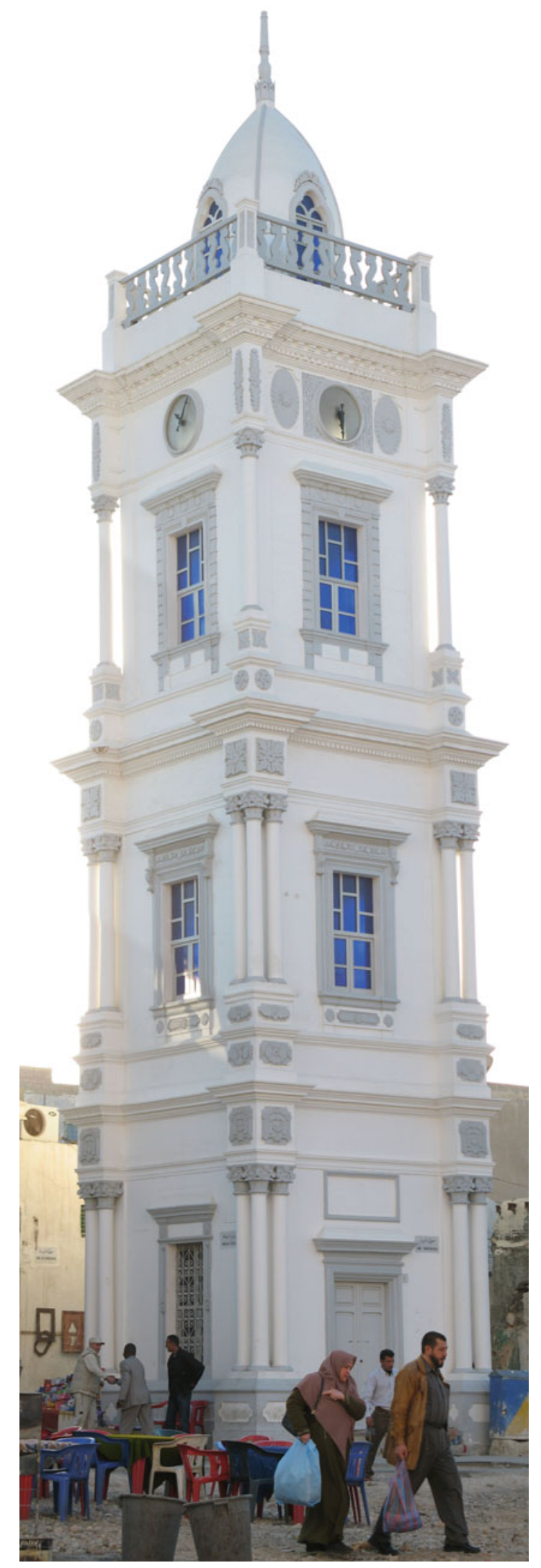

Fig. 2.11 Clock tower, a landmark of the medina, is the only surviving tower from the Ottoman period and was built during the second half of the nineteenth century
Among them, was the assassination of the minister for Palace affairs, Ibrahim al-Shalhi, by a member of the royal family in 1954. This event had considerable negative implications on the state. Another issue facing the Libyan state problem derived from the lack of a direct heir.

The economic situation in Libya improved considerably with the discovery and exportation of petroleum in 1961. This development greatly influenced various sectors of life in Libya. Soon, a five-year plan was put in place. The oil revenues enabled Libya to support the Palestinian cause, on the one hand, and the Arab frontline countries after the June 1967 war, on the other.

A number of factors led to the fall of the Libyan monarchy. In the year 1964, popular protests were organised against the foreign bases on Libyan soil. Other demonstrations took to the streets, as a result of the conflict between Israel and Egypt in 1967. The internal situation within the Libyan regime, characterised by various crises and the proliferation of political blocs, resulted in the alternation of eleven governments in eighteen years. A number of military officers, belonging to the lower ranks, carried out a military coup on 1 September 1969. They soon set up the Revolutionary Command Council to administer the country, and in their first declaration, they stated that the official name of Libya would be the Libyan Arab Republic. They specified their guiding principles, namely freedom, socialism and unity. They also stated that they would be eradicating corruption, bribery and favouritism.

Libya was greatly influenced by the internal and external policies adopted by Muammar al Gaddafi as President of the Revolutionary Command Council. One could consider his speech in the city of Zuara in 1973 as a decisive juncture, which expressed the domination over power. In that speech, he declared the suspension of all Libyan laws, as well as the so-called Cultural Revolution. Subsequently, on 2 March 1977, al Gaddafi declared the ushering of the People's Power, and the establishment of the Socialist Peoples Libyan Arab Jamahiriya (Fig. 2.12). Libya suffered great political and economic problems, among them, the suffocation of liberties, the control over commerce, the involvement in external wars, such as the war in Chad, confrontation with Egypt and the interference in internal affairs of other countries. A series of executions were announced via the mass media in the holy month of Ramadan, in addition to the infamous Abu Salim massacre.

On 17 February 2011, a number of factors led to the Libyan people rising up in peaceful demonstrations which were brutally confronted by the regime. This led to the people taking up arms and defending themselves. Faced with the people's will, the regime had no other possibility but to give in. Tripoli, the capital city, was liberated on 20 August 2011. Subsequently, on 23 October 2011, the National Transitional Council, from the city of Benghazi, declared the total liberation of Libya. ${ }^{12}$ 


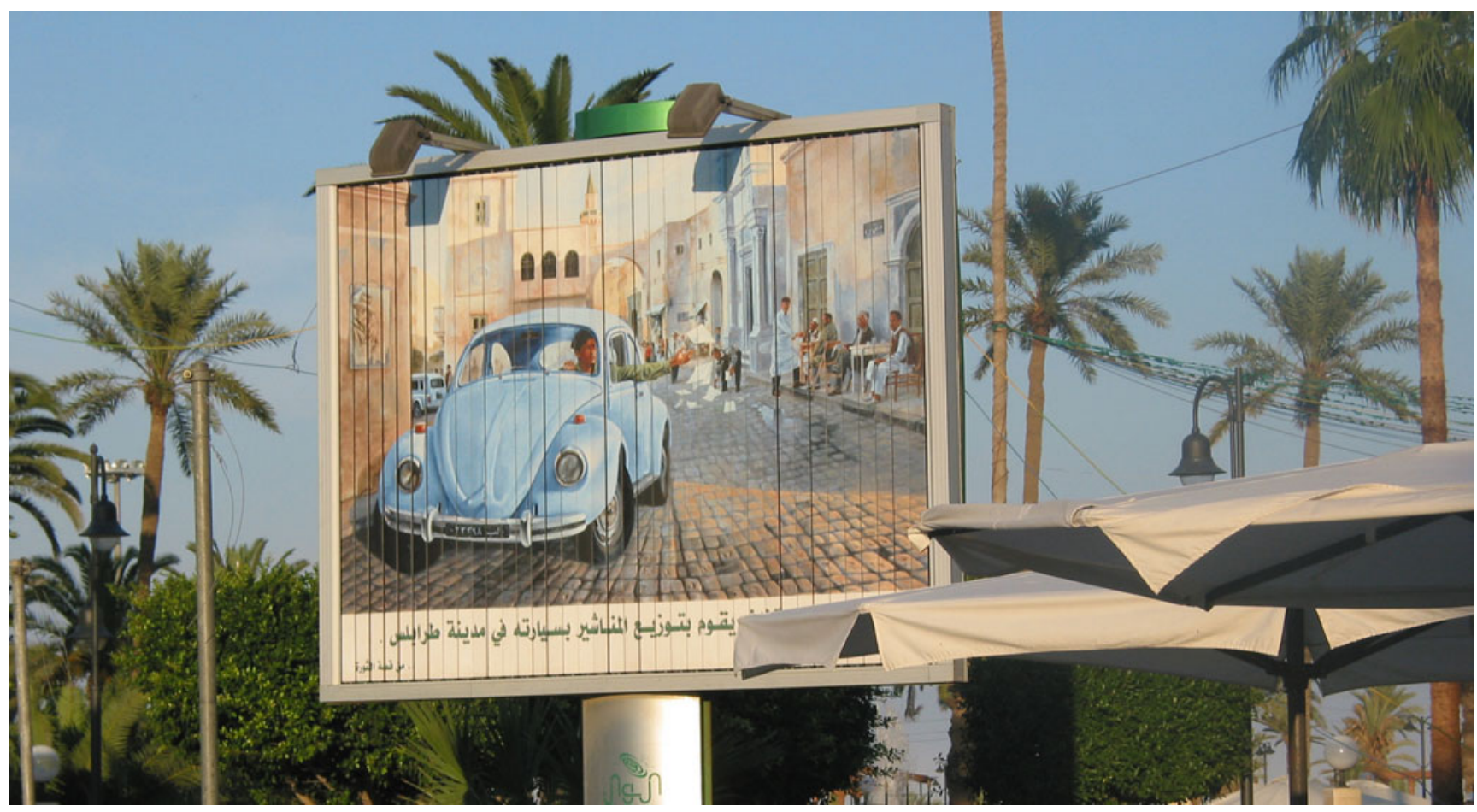

Fig. 2.12 Al Gaddafi left various imprints all over Libya, many of which were eradicated

\section{Notes}

1. Herodot (2004).

2. Schmidt-Colinet (1979), Kirsten (1961).

3. Di Vita et al. (1999).

4. Di Vita et al. (1999), Kirsten (1961).

5. Di Vita et al. (1999), Mattingly (1995); Reynolds and Ward Perkins (1952).

6. Alföldy (1987).

7. Di Vita et al. (1999), Mattingly (1995).

8. Squarciapino (1966).

9. Weis (1996).
10. Di Vita et al. (1999), Mattingly (1995), Teutsch (1962), Charles-Picard (1962).

11. Al Hakam, Futuh misr wa-l-magrib, Al-Tijani (1958), Ghalbun (1960); al Ansari (1967) al manhal al adb fi tarihTarabuls al-Garb, Rossi (1974), Abbas (1970), Thiry (2004), at-Tillisi (1985), Hamid (1978), Vireau (1973), Az-Zawi (1963), al-Barghuthi (1973), Bernia (1969).

12. Al Ansari (1967) al manhal al adb fi tarih Tarabuls al-Garb, Rossi (1974), Abbas (1970), Thiry (2004), Tillisi (1985), Hamid (1978), Vireau (1973), Az Zawi (1963), al Barghuthi (1973), Bernia (1969).
Open Access This chapter is licensed under the terms of the Creative Commons Attribution 4.0 International License (http:// creativecommons.org/licenses/by/4.0/), which permits use, sharing, adaptation, distribution and reproduction in any medium or format, as long as you give appropriate credit to the original author(s) and the source, provide a link to the Creative Commons license and indicate if changes were made.
The images or other third party material in this chapter are included in the chapter's Creative Commons license, unless indicated otherwise in a credit line to the material. If material is not included in the chapter's Creative Commons license and your intended use is not permitted by statutory regulation or exceeds the permitted use, you will need to obtain permission directly from the copyright holder.

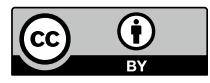

